\title{
MOLECULAR BASIS AND INTEGRATIVE ANALYSIS OF Rv1463 AS PROBABLE CONSERVED ATP-BINDING PROTEIN BY COMPUTATIONAL APPROACH
}

\author{
RV1463 OLASI KORUNMUŞ ATP BA ĞLAYICI PROTEININ HESAPLAMALI YAKLAŞIMLA \\ MOLEKÜLER TEMEL BÜTÜNLEŞTIRICII ANALIZİ
}

\section{Md Amjad BEG ${ }^{1}$ D, Mustafa SEVINDIK ${ }^{1, *}$ (D), Shahid Tanweer HAIDER ${ }^{1}$ (D), Preeti SONI ${ }^{3}$ (D),

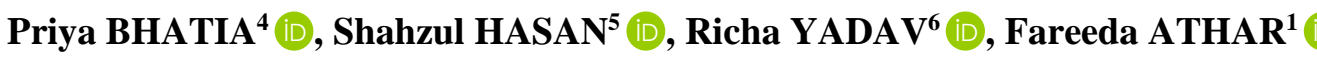

${ }^{1}$ Jamia Millia Islamia University, Centre for Interdisciplinary Research in Basic Science, 110025, New Delhi, India

${ }^{2}$ Osmaniye Korkut Ata University, Bahçe Vocational School, Department of Food Processing, 80500, Osmaniye, Turkey

${ }^{3}$ Shri Guru Ram Rai PG College, Department of Microbiology, 248001, Uttarakhand, India ${ }^{4}$ Apeejay Stya University, School of Bioscience, 122103, Haryana, India

${ }^{5}$ Jamia Millia Islamia University, Department of Biotechnology, 110025, New Delhi, India

${ }^{6}$ Kanya Gurukul Mahavidyalaya University, Department of Microbiology, 249404, Uttarakhand, India

\section{ABSTRACT}

Objective: Tuberculosis as a global epidemic since years due to vigorously changing dynamics of its causal pathogen, Mycobacterium tuberculosis $H_{37} R v$ (M. tuberculosis). This pathogen has worsened the situation therefore making it so challenging and hard to overcome. In this manuscript, we have used the computational approaches for ATP-binding protein of Mycobacterium tuberculosis $H_{37} R v$ (M. tuberculosis) that helps in transportation of metal ion across the plasma membranes and resultant generating an electrochemical gradient. Rv1463 a hypothetical protein possessing ATP binding motif (WalkerA) $(G X X X X G K S / T)$, and (Walker B) (DEXXXXXD) and significance of these motifs in ATP binding and hydrolyzing activities. It shows the ATP-binding property by interacting with transcriptional regulatory protein and showing the interacted compounds as magnesium (Mg) and Adenosine di phosphate (ADP).

\footnotetext{
* Corresponding Author/Sorumlu Yazar: Mustafa Sevindik e-mail /e-posta: sevindik27@gmail.com
} 
Material and Method: The structure of Rv1463 has been build by the Swiss Model webserver and molecular docking was done using AutoDock.

Result and Discussion: In the mutational analysis which confirms that D175 residues was common in all interactions which may change the protein conformation. These computational approaches can be helpful in developing new strategies in treatment of this disease.

Keywords: Molecular docking, Mycobacterium tuberculosis, Rv1463, tuberculosis

\section{ÖZ}

Amaç: Tüberküloz, patojeni olan Mycobacterium tuberculosis H37Rv'nin (M. tuberculosis) şiddetle değişen dinamiği nedeniyle yıllardan beri küresel bir salgın olmuştur. Bu patojenin durumu daha da kötüleşmektedir ve üstesinden gelmek zorlaşmaktadır. Bu yazıda, metal iyonunun plazma membranları boyunca taşınmasına yardımcı olan ve sonuçta bir elektrokimyasal gradyan oluşturan Mycobacterium tuberculosis H37Rv'nin (M. tuberculosis) ATP bağlayıcı proteini için hesaplama yaklaşımlarını kullandı. Rv1463, ATP bağlama motifi (WalkerA) (GXXXXGKS / T) ve (Walkera) (DEXXXXXD) içeren varsayımsal bir protein ve bu motiflerin ATP bağlama ve hidrolizleme aktivitelerindeki önemi üzerinde duruldu. ATP bağlanma özelliğini, transkripsiyonel düzenleyici protein ile etkileşime girerek ve etkileşimli bileşikler magnezyum (Mg) ve Adenosin di fosfat $(A D P)$ ile gösterir.

Gereç ve Yöntem: Rv1463'ün yapısı SwissModel web sunucusu tarafindan oluşturuldu ve AutoDock kullanılarak moleküler yerleştirme yapıldı.

Sonuç ve Tartışma: Mutasyonel analizde, D175 kalıntılarının protein yapısını değiştirebilecek tüm etkileşimlerde ortak olduğunu doğruland. Bu hesaplama yaklaşımları, bu hastalığın tedavisinde yeni stratejiler geliştirmede yardımc olabilir.

Anahtar Kelimeler: Moleküler kenetlenme, Mycobacterium tuberculosis, rv1463, tüberküloz

\section{INTRODUCTION}

Tuberculosis (TB) has become one of the major causes of death in many countries due to its highly infectious effect and is deadly in combination with the human immunodeficiency virus (HIV) [1]. Mycobacterium tuberculosis $\mathrm{H}_{37} \mathrm{Rv}$ (M. tuberculosis) is unique in its way as it do not contain a phospholipids external layer, secondly, it is acid-fast Gram-positive bacterium that do not take up the stains because of the high lipid and Mycolic acid content of its cell wall [2-4]. Though it is a pulmonary disease but sometimes it can also occur in other parts of the body like the brain, genital parts, eye, etc. Exceptionally, Mycobacterium tuberculosis $\mathrm{H}_{37} \mathrm{Rv}$ (M. tuberculosis), can persist inactively for a very long time in the alveolar macrophages by developing a permanent structure known as granuloma [5-7]. With great achievement in treating this disease, though the frequency of TB has been reduced to a good amount worldwide, but with the emergence of multidrug-resistant (MDR) and extensively drug-resistant (XDR) TB another extraordinary feature of this bacterium highlighted as it modified its molecular system [8,9]. Among many features of this bacterium that is responsible for its virulence, one of them is its ATP binding and hydrolyzing proteins which are responsible for various cellular mechanisms like cell signaling, cellular energetic, etc. One of the examples of ATP binding and hydrolyzing genes are $\mathrm{ABC}$ transporters family [10]. $\mathrm{ABC}$ transporter family is one of the huge and prominent superfamily of transporters gene that contributes widely in various physio-chemical processes taking place in a living cell [11]. The process of transportation conducted by ABC transporters is promoted by ATP. The process includes the binding of nuclear binding domains (NBDs) of ABC transporters with the Adenine 
triphosphate (ATP) and followed by ATP hydrolysis for energy production required for this process to be carried out. NBD is the most conserved domain of the transporters, having all about 40-45\% conserved sequences, irrespective of their substrate specificity and their origin [12,13]. Approximately all NBD-containing proteins are responsible for the transportation of substrate across the plasma membranes. In prokaryotes, the assembly of these domains is somewhat different as this is often found that separate subunits are assembled into a membrane-bound complex whereas in eukaryotes they are found to be fused into a single polypeptide chain [14].

The NBDs of ABC transporters performs various functions like ATP binding and hydrolysis, own highly conserved amino acid sequences, like the Walker (ATP/GTP binding site motif which can be described as [AG-x(4)-G-K-[ST], where $\mathrm{X}$ is any amino acid), the Walker ${ }_{\mathrm{B}}$ (ATP/GTP binding site

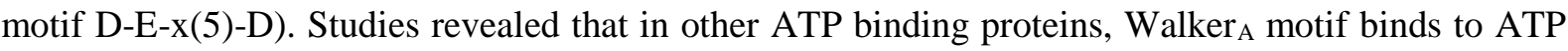
by the assistance of the oxygen molecules of the $\beta$-and $\gamma$-phosphates on the examined amino acids like lysine and glycine of the respective motif [15-17]. Membranous proteins like ATPases perform functions like the folding of proteins and degradation of proteins, replication initiation, DNA repair mechanism, and the transport of substances across the membrane using the energy released during ATP hydrolysis $[18,19]$. Some ATPases of M. tuberculosis like P-type ATPases are induced during infection only and play a key role in the survival of bacilli [20]. Highpoints of this manuscript include essential features of Rv1463 and provide important informations regarding the untouched sites of this bacterium that might provide a significant aspect of the molecular mechanisms involved in pathogenesis.

\section{MATERIAL AND METHOD}

\section{Conserved hypothetical protein Rv1463 contain ATP binding motifs}

M. tuberculosis genome has 4173 genes and database provides the most accurate annotation and is an appropriate tool to find out genomics and proteomics studies of this pathogenic mycobacteria. Mycobrowser database (https://mycobrowser.epfl.ch/genes/) is a large database server and a huge depository for the comprehensive genomic and proteomic study of mycobacteria species [21,22]. To study the sequence alignment between Rv1460 and Rv1463 was done by Clustal Omega, which is more truthful than earlier versions, it is allowing the large dataset to be aligned and having multiple processors which measured by a range of well-liked benchmarks [23,24]. To study the protein-protein interaction using STRING database (https://string-db.org/) contain a large amount of data including chemical properties and protein structures. These servers are implemented for the functionality aspect to differentiate between the proteins and chemicals not required for study purposes. The interpretation of the interaction result shown separately for each data and the cutoff value as low confidence: scores $<0.4$; medium: 0.4 to 0.7 ; high: $>0.7[25,26]$. 


\section{Protein subcellular localization}

The localization of the Rv1463 studies gave beneficiary results for our analysis; we could easily do this by the TBpred and CELLO2GO server. TBpred (http://crdd.osdd.net/raghava/tbpred/) is an SVM-based server to predict the Mycobacterial protein localization. TBpred helps in predicting the protein localization in the cytoplasm, integral membrane, lipid-anchored, and secreted proteins [27]. Cello2Go webserver (http://cello.life.nctu.edu.tw/cello2go/) predicted the localization and the gene ontology annotation like molecular function, biological process, and cellular component [28,29].

\section{Molecular modeling and Model validation}

Molecular modeling demonstrates the presentation of atoms which facilitates through intensely précised (i.e. superior to test) numerical recreation, utilizing hypothetical information to determine the functions of protein [30]. Before the molecular modeling, we first predicted the two-dimensional structure of Rv1463 by using PSIPRED webserver [31]. The 3D model of the protein is essential for predicting the functions of protein and protein structure from its sequence is a challenging task for biologists but with the advancement, in technologies, we can easily predict the 3D structure of a protein by using an online webserver. Swiss Model is an online webserver that predicted the 3D model because of template-based modeling such as homology modeling which is one of the most consistent methods for producing the realistic 3D structure. With the help of modeling, we have discovered the drug, designing of ligand, sorting of the compounds on libraries, simulation studies of molecules their properties and behavior on an atomic level, etc. The cutoff estimation of the Swiss model as GMQE and QSQE means the quality estimation which combines properties from the target-template alignment and the template structure and qualitative model energy analysis which describing the major geometrical aspects of protein structures [32-34]. SAVES metaserver validated the predicted 3D modeled structure. Here the Ramachandran plot shows the overall geometry of the model which demonstrates the validated score and result which includes favored, allowed, and disallowed regions [35-37].

\section{Molecular docking of Rv1463 with Phosphate, FDA approved TB drugs, and identify Natural inhibitors}

Because of the drug resistance, it becomes so difficult to cure the disease pattern. The basic orientation between the receptor and the compound is provided by molecular docking analysis which was done by AutoDock Vina. For receptor preparation, the grid parameter was saved in CONF file. By using molecular docking, using pyrimidine nucleotide ADP, ATP, and FDA-approved TB drugs [3840]. Discovery Studio BIOVIA (Discovery Studio Visualizer) has analyzed the 2D ligand-receptor interaction analysis of Rv1463 complexes which suggested the interacted residues in active sites and therefore further mutation analysis at these residues was done to confirm whether this mutation destabilizes protein or not [41]. 


\section{Structural based mutation-induced stability deviations}

At present, the prediction of the mutations can be done accurately with the help of various evolutionary tools [42]. In mutational analysis prediction by the physiochemical hypothesis can predict and can accurately measure the information which created the exact and versatile in silico way to deal with the mutation stability and changes that occur in the structure by the sequence-based predictions [43-44]. This study provides information regarding the protein stability results from a single point mutation. In this way, understanding has been created regarding the impacts of protein due to changes that occurred in the structure and connecting them with the size of the entire proteome.

\section{RESULT AND DISCUSSION}

\section{Conserved hypothetical protein Rv1463 contain ATP binding motifs}

In prokaryotes, the two ATP molecules are sandwiched between the Walker $_{\mathrm{A}}(\mathrm{ATP}$ binding site motif A) (GX(4) GKS/T), and Walker a (ATP binding site motif B) (DEXXXXXD) motifs of one monomer of $\mathrm{ABC}$ transporter [15,16]. After the sequence has retrieved from the Mycobrowser database showing Rv1463 has 801 bp gene length which means the protein length is 266 amino acids [20]. We have used the FASTA format amino acid sequence for sequence alignment by Clustal Omega to find out the similar region in between Rv1460 and Rv1463 and there is 51 percent good alignment else rest sequence shows average identity $[23,24]$. Here, in sequence alignment the ATP binding motifs A and B (GX(4)GKS/T and DEX(5)D) showing in the black outline (see Figure 1). Further analysis of Rv1463 protein-protein interaction was done by STRING database showing its interaction with Rv1461, Rv1462, csd, Rv1465, Rv1466, Rv1460, Rv3778c, Rv3284, Rv1459c and Rv2204c it listed here from increasing to decreasing order according to the predicted score (see Figure 1) $[25,26]$. The interacting functional partner Rv1463 is the ATP-binding protein ABC transporter and the highest interaction score with Rv1461 and Rv1462 is 0.999 is the outstanding outcome.

\section{Protein subcellular localization}

The predicted outcome of the subcellular localization was done by TBpred and CELLO2GO webserver and here it is predicted Rv1463 as a cytoplasmic protein which score is 2.8665111 cleared by amino acid composition based SVM method [27]. Using CELLO2GO prediction the protein topology and annotation of Rv1463 showing the localization in the cytoplasmic region with $96.7 \%$ else predicted the outcome of molecular function as ATPase activity with 27.2\%, the biological process and cellular component (see Figure 2) [28]. 


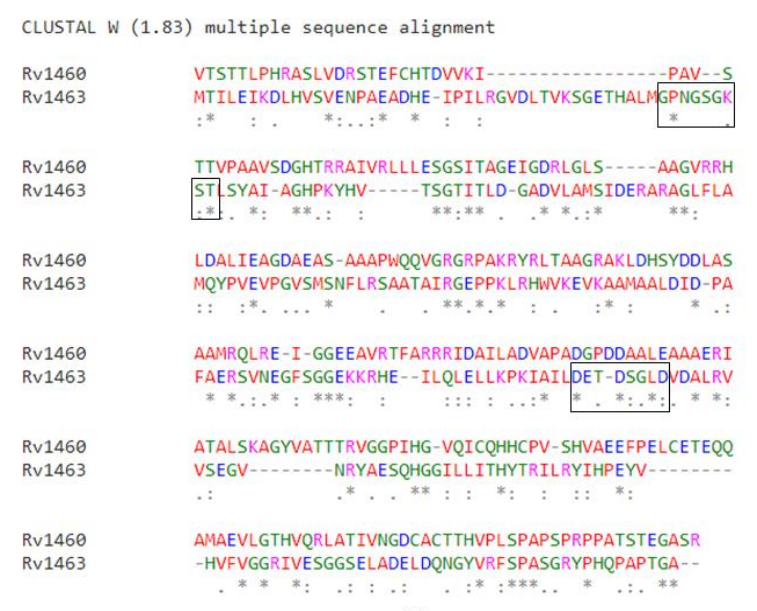

(a)

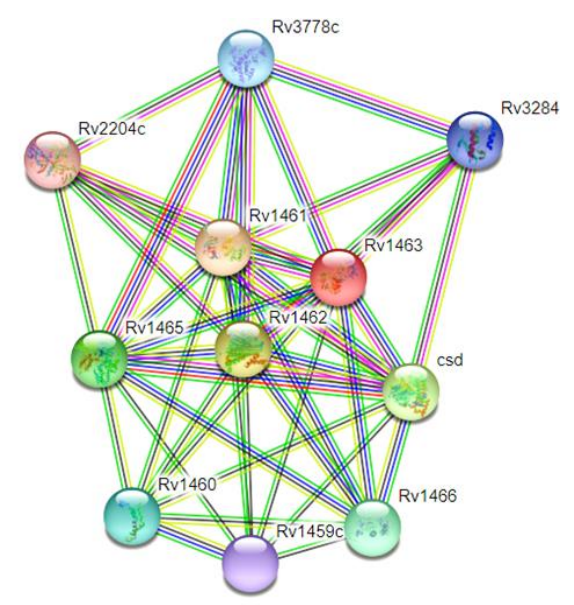

(b)

Figure 1. Conserved hypothetical protein Rv1463 contain ATP binding motifs: (a) Clustal Omega result outcome demonstrates multiple sequence alignment of Rv1463 and Rv1460 protein where the homology is shown $51 \%$ good alignment and a black box showing the ATP-binding motifs (A and B). (b) The protein-protein interaction of Rv1463 protein depicts here Rv1461 and Rv1462 is the highest scorer 0.999.

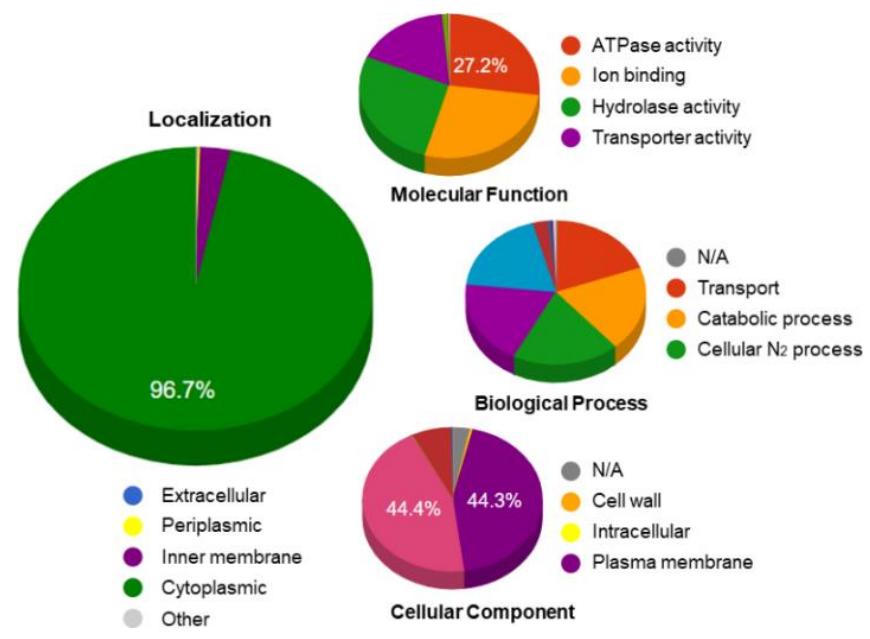

Figure 2. Protein subcellular localization: CELLO2GO webserver predictions are shown in these pie charts which showed the predicted localization and gene annotation.

\section{Molecular modeling and Model validation}

The secondary structure prediction was done by the PSIPRED webserver which shows this protein has $36.46 \% \alpha$-helix, $22.55 \% \beta$-sheet, and $40.99 \%$ coiled region (see Figure 3) [31]. Finally, the three-dimensional structure prediction of the protein is used for the many essential biophysical and biochemical errands. For molecular modeling the FASTA format amino acid sequence retrieved from the Mycobrowser and using Swiss Model webserver, is based on the template-based homology 
modeling. After acquiescing the amino acid sequence the best template comes out PDB ID: 2D2E which is SurfC protein (Crystal structure of atypical ABC-ATPase SurfC from Thermus thermophilus HB8) with 56.43\% identity. The predicted model of Rv1463 is a monomer oligo state and no ligand bound with it the cutoff estimation of the GMQE is 0.70 and QMEAN is -0.30 with the satisfactory result where the $100 \%$ residues are modeled (see Figure 4) [34,35]. Modeled protein of Rv1463 validated by the Ramachandran plot analysis which is done by SAVES metaserver (PROCHECK). After analysis of the Ramachandran plot of our modeled protein, the structure of Rv1463 showed that $94.8 \%$ of residues have passed the criteria of most favored regions. Although, the other additional allowed residues of $4.7 \%$ and the disallowed region is $0.5 \%$. The RAMPAGE server predicted the protein structure based on $\varphi, \psi$ angle of individual residues (see Figure 5) [36-38].

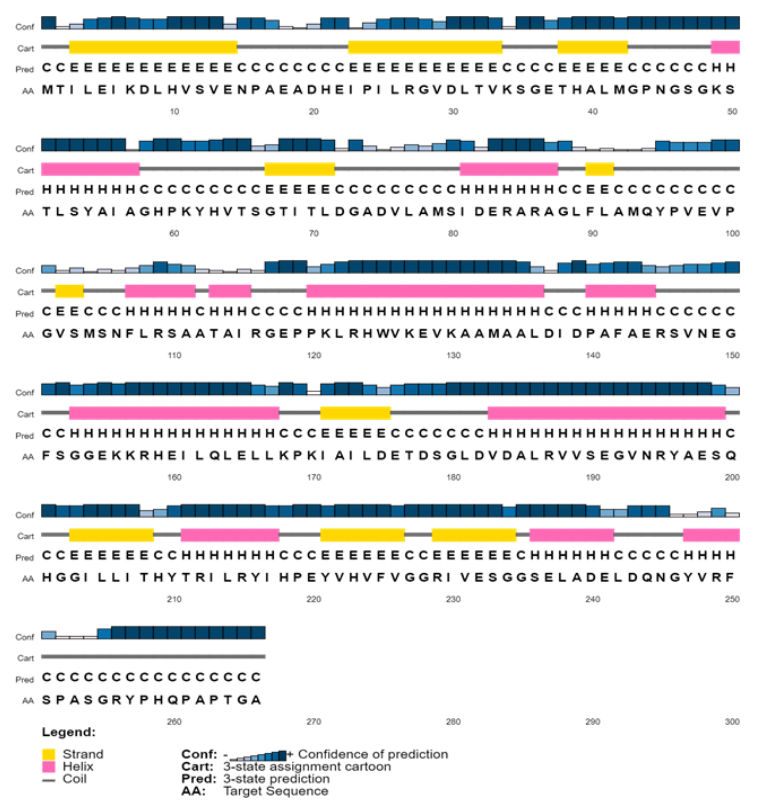

Figure 3. PSIPRED webserver predicted the secondary structure in this graphical output shows $11 \alpha$-helices extends and $10 \beta$-strands which score $36.46 \% \alpha$-helix, $22.55 \% \beta$-sheet and $40.99 \%$ coiled region.

\section{Molecular docking of Rv1463 with Pyrimidine nucleotide and FDA approved TB drugs}

The basic orientations between the receptor and the compound are provided by docking studie s using AutoDock Vina. For the ligand-receptor preparation as the pdbqt form following the given steps [39]. After the ligand receptor preparation set the grid parameter in CONF file for the site-specific docking in the active site (see Figure 6). The set parameter of the CONF file is center X-7.148, Y56.976, and Z-29.242 whereas the size X-24, Y-26, and Z-22. In the molecular docking studies with the pyrimidine nucleotide ADP and ATP, the docking score of the ADP is $-8.5 \mathrm{kcal} / \mathrm{mol}$ and ATP is -6.7 $\mathrm{kcal} / \mathrm{mol}$. 


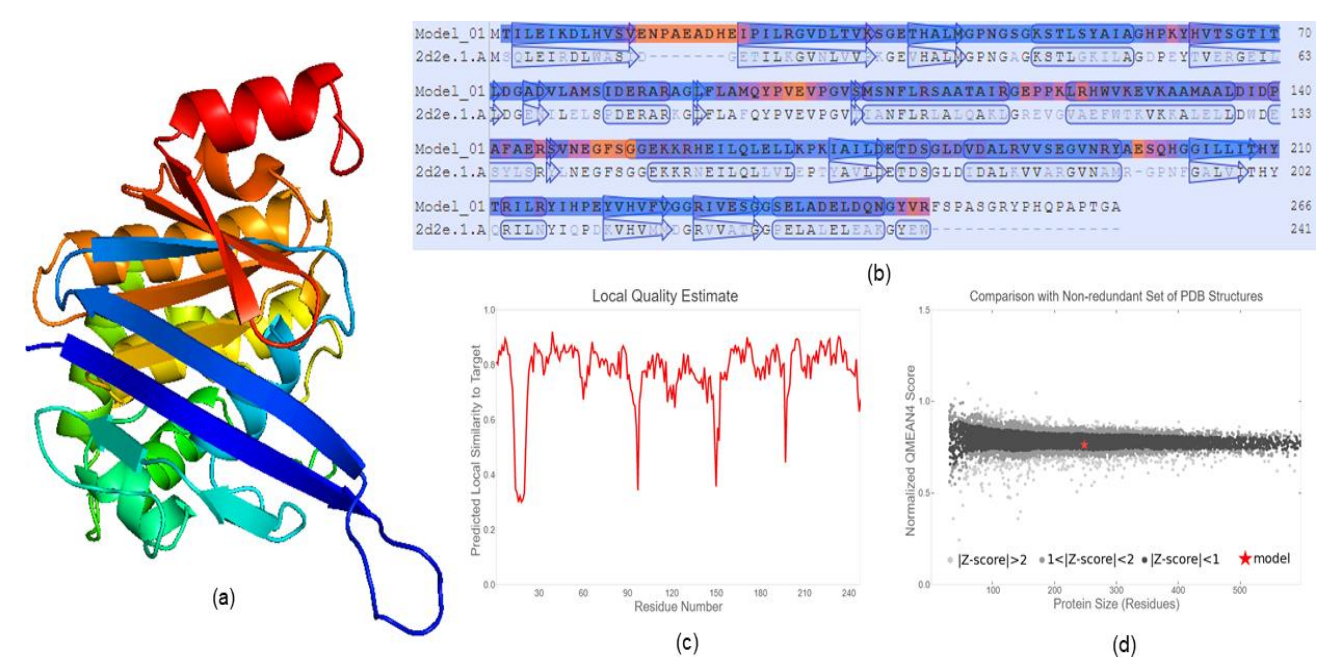

Figure 4. Protein modeling using Swiss Model webserver (a) Rv1463 predicted model cartoon represents (b) The PDB 2D2E template alignment. (c) Local quality estimate graph (d) Model lies in the non-redundant set of PDB structures.

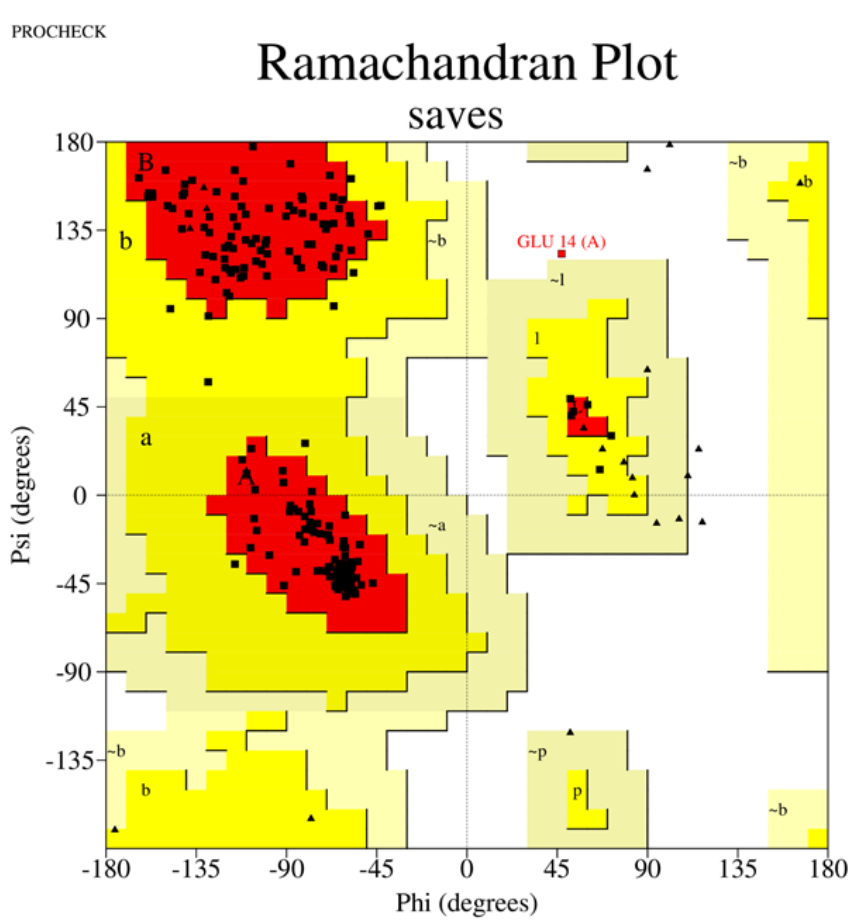

Figure 5. Model validation by using SAVES (PROCHECK) server here the Ramachandran plot shows $94.8 \%$ residues are in the most favored region.

Docking studies against the FDA-approved TB drugs the selected high binding affinity score targets are Clofazimine $-8.4 \mathrm{kcal} / \mathrm{mol}$ and Delamanid $-8.3 \mathrm{kcal} / \mathrm{mol}$. They both are used in the treatment of the drug-resistant TB. Clofazimine works by binding to the guanine bases, thereby blocking the DNA 
template and inhibiting bacterial proliferation. Delamanid inhibits the synthesis of a component of the mycobacterial cell wall as mycolic acid and ketomycolic acid [40,41]. By using BIOVIA tool to analyze the two-dimensional interaction between ligand-receptor we found that the pyrimidine nucleotide and TB drugs have some similar interacted residues ILE173 and ASP175 else interacted residues within the active pocket (see Figure 7) [42].

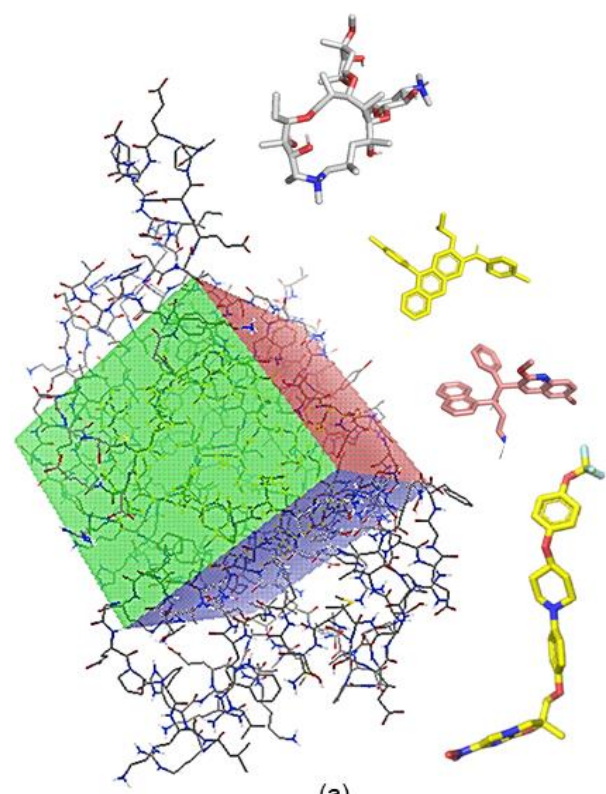

(a)

Figure 6. Preparation of the grid box related to Site specific docking here, possible bindings of all of the ligands within the active sites in the box.

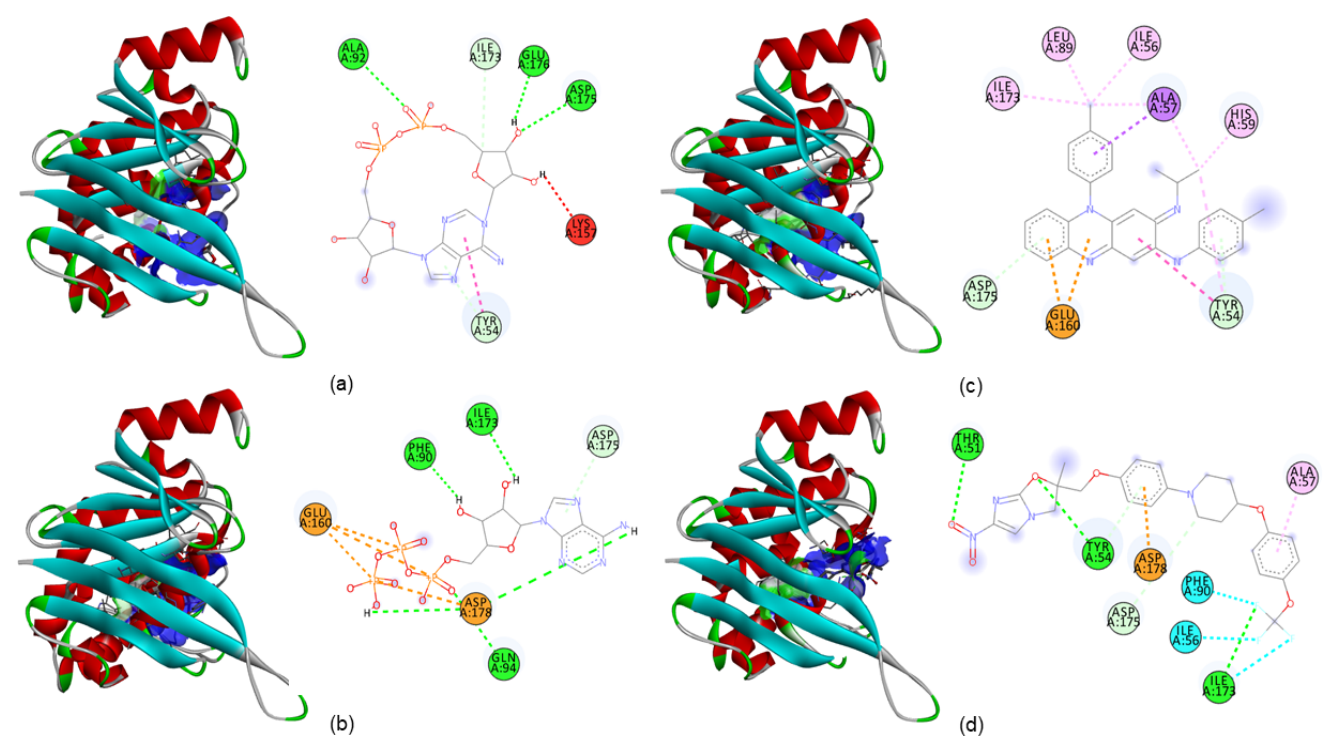

Figure 7. 2D interaction analysis of the pyrimidine nucleotide (a) ADP (b) ATP and TB drugs (c) Clofazimine and (d) Delamanid. 


\section{Structural based mutation-induced stability deviations}

The mutation analysis at the respective residues i.e. ILE173 and ASP175 was done by DynaMut webserver which confirms whether this mutation destabilizes protein or not. In protein stability after the single point amino acid mutation with other Nucleophilic, Hydrophobic, Aromatic, Acidic, Amide and basic amino acid of Rv1463 which evaluate the mutational amino acid in ( $\mathrm{kcal} / \mathrm{mol})$ value which defines that negative values of the mutated residues and decreases the protein stability $[43,44]$. The mutational analysis predicted the Rv1463 protein was maximally destabilizing on position ASP175 by changing Aspartate into Alanine (ASP175ALA) and Glycine (ASP175GLY). The predicted destability value mostly destabilizing on positioned Aspartate into Alanine $-0.583 \mathrm{kcal} / \mathrm{mol}$ and Aspartate into Glycine $0.379 \mathrm{kcal} / \mathrm{mol}$. Here, Aspartate into Alanine (ASP175ALA) mutation predicted as the most destabilizing and it will destabilize the protein conformation (see Figure 8) [45-47]. As many studies already revealed the importance of ATP binding genes in various biological processes of living organisms, thus this work delivers importance of Rv1463 as different and interesting part for understanding the molecular mechanism of survival of this bacterium.

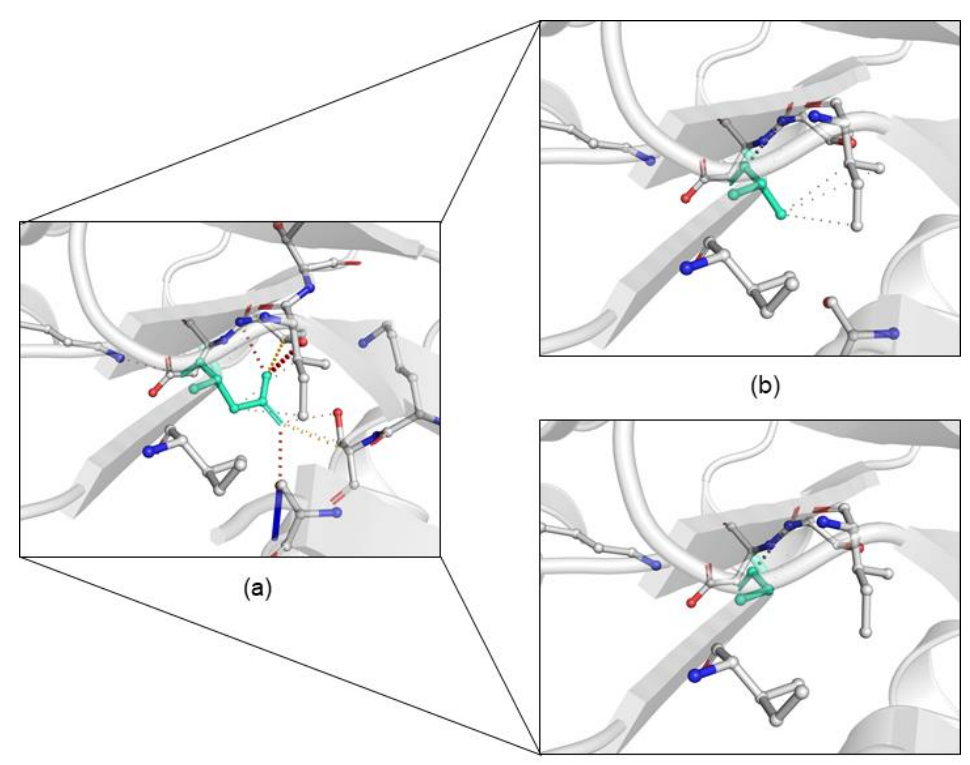

(c)

Figure 8. In mutation analysis on selected residues ASP175 for visualizing the drastic changes in interatomic interaction between (a) wildtype (b) mutant (ASP175ALA) and (c) mutant (ASP175GLY) which shows mutation showing the bond disruptions which predicted drastic changes in protein stability.

This worldwide threat mystified the new discoveries by developing resistance to each line drugs and increases the mortality rate worldwide. This situation demands for innovative way to deal with this bacillus and reduce this global problem. In our current study it emphasizes that these proteins can be 
used as a potential target for developing anti -TB approaches. Rv1463 is conserved hypothetical protein whose function are still unknown and not studied earlier as well. Rv1463 contains both ATP binding motifs A and B (GX(4)GKS/T and DEX(5)D) and many other properties which resemble that it with an ATP binding and $\mathrm{ABC}$ transporter gene. This study provides essential characteristics of the potential ATP binding properties. Mutational analysis predicted the essentiality of ASP175 residue of the Rv1463 which mutated with Alanine has destabilize the protein conformational changes in the stability. As discussed earlier the importance of ATP molecule which helps in the survival and pathogenesis of $M$. tuberculosis, so disruption in these genes can disrupt the bacilli pathogenesis and its survival rate. These might be used as potential novel drug target.

\section{ACKNOWLEDGEMENTS}

The author Md. Amjad Beg also acknowledges University Grants Commission Maulana Azad National Fellowship for the support and Jamia Millia Islamia University.

\section{AUTHOR CONTRIBUTIONS}

Conception: M.A.B.; Design: M.A.B., S.T.H., P.B., R.Y.; Supervision: M.A.B., M.S., S.T.H., P.B.; Resources: M.A.B., S.T.H., P.S., P.B.; Materials: M.A.B., P.S., S.H., F.A.; Data collection and/or processing: M.A.B., M.S., P.B., S.H.; Analysis and/or interpretation: M.A.B., M.S., R.Y., F.A.; Literature search: M.A.B., M.S., S.T.H., P.S., R.Y.; Writing manuscript: M.A.B., F.A.; Critical review: M.A.B., M.S., S.H., F.A.; Other: -

\section{CONFLICT OF INTEREST}

The authors declare no conflict of interest.

\section{REFERENCES}

1. Simmons, J.D., Stein, C.M., Seshadri, C., Campo, M., Alter, G., Fortune, S., Schurr, E., Wallis, R.S., Churchyard, G., Mayanja-Kizza, H., Boom, W.H., Hawn, T.R. (2018). Immunological mechanisms of human resistance to persistent Mycobacterium tuberculosis infection. Nature Reviews Immunology, 18(9), 575 - 589.

2. Brennan, P.J. (2003). Structure, function, and biogenesis of the cell wall of Mycobacterium tuberculosis. Tuberculosis, 83(1-3), $91-97$.

3. Beg, M.A., Shivangi Thakur S.C., Meena, L.S. (2018). Structural Prediction and Mutational Analysis of Rv3906c Gene of Mycobacterium tuberculosis H37Rv to Determine Its Essentiality in Survival. Advances in Bioinformatics, 6152014. 
4. Glaziou, P., Floyd, K., Raviglione, M.C. (2018). Global Epidemiology of Tuberculosis. Seminars in Respiratory and Critical Care Medicine, 39(3), 271 - 285.

5. Ndlovu, H., Marakalala, M.J. (2016). Granulomas and Inflammation: Host-Directed Therapies for Tuberculosis. Frontiers in Immunology, 7, 434.

6. Silva Miranda, M., Breiman, A., Allain, S., Deknuydt, F., Altare, F. (2012). The tuberculous granuloma: an unsuccessful host defence mechanism providing a safety shelter for the bacteria? Clinical and Developmental Immunology, 139127.

7. Russell, D.G., Cardona, P.J., Kim, M.J., Allain, S., Altare, F. (2009). Foamy macrophages and the progression of the human tuberculosis granuloma. Nature Immunology, 10(9), $943-948$.

8. Gandhi, N.R., Nunn, P., Dheda, K., Schaaf, H.S., Zignol, M., van Soolingen, D., Jensen, P., Bayona, J. (2010). Multidrug-resistant and extensively drug-resistant tuberculosis: a threat to global control of tuberculosis. The Lancet, 375(9728), 1830 - 1843.

9. Shivangi, Beg, A., Meena, S., Meena, L.S. (2017). To Find out the Essentiality of Rv0526 Gene in Virulence of Mycobacterium Tuberculosis by using in silico Approaches. Open Journal of Bacteriology, 1(1), $13-15$.

10. Qiu, W., Liesa, M., Carpenter, E.P., Shirihai, O.S. (2015). ATP Binding and Hydrolysis Properties of ABCB10 and Their Regulation by Glutathione. PLoS One, 10(6),e0129772.

11. Braibant, M., Gilot, P., Content, J. (2000). The ATP binding cassette (ABC) transport systems of Mycobacterium tuberculosis. FEMS Microbiology Reviews, 24(4), 449 - 467.

12. Cassio Barreto de Oliveira, M., Balan, A. (2020). The ATP-Binding Cassette (ABC) Transport Systems in Mycobacterium tuberculosis: Structure, Function, and Possible Targets for Therapeutics. Biology, 9(12),E443.

13. Soni, D.K., Dubey, S.K., Bhatnagar, R. (2020). ATP-binding cassette (ABC) import systems of Mycobacterium tuberculosis: target for drug and vaccine development. Emerging Microbes \& Infections, 9(1), $207-220$.

14. Balakrishnan, L., Venter, H., Shilling, R.A., van Veen, H.W. (2004). Reversible transport by the ATP-binding cassette multidrug export pump LmrA: ATP synthesis at the expense of downhill ethidium uptake. Journal of Biological Chemistry, 279(12), 11273 - 11280.

15. Ambudkar, S.V., Kim, I.W., Xia, D., Sauna, Z.E. (2006). The A-loop, a novel conserved aromatic acid subdomain upstream of the Walker A motif in ABC transporters, is critical for ATP binding. FEBS Letters, 580(4), 1049 - 1055.

16. Orelle, C., Dalmas, O., Gros, P., Di Pietro, A., Jault, J.M. (2003). The conserved glutamate residue adjacent to the Walker-B motif is the catalytic base for ATP hydrolysis in the ATP-binding cassette transporter BmrA. Journal of Biological Chemistry, 278(47), 47002 - 47008.

17. Chen, M., Abele, R., Tampé, R. (2004). Functional non-equivalence of ATP-binding cassette signature motifs in the transporter associated with antigen processing (TAP). Journal of Biological Chemistry, 279(44), 46073 - 46081. 
18. Vinothkumar, K.R., Henderson, R. (2010). Structures of membrane proteins. Quarterly Reviews of Biophysics, 43(1), 65 - 158.

19. Marinko, J.T., Huang, H., Penn, W.D., Capra, J.A., Schlebach, J.P., Sanders, C.R. (2019). Folding and Misfolding of Human Membrane Proteins in Health and Disease: From Single Molecules to Cellular Proteostasis. Chemical Reviews, 119(9), 5537 - 5606.

20. Hung, L.W., Wang, I.X., Nikaido, K., Liu, P.Q., Ames, G.F., Kim, S.H. (1998). Crystal structure of the ATP-binding subunit of an ABC transporter. Nature, 396(6712), 703 - 707.

21. Kapopoulou, A., Lew, J.M., Cole, S.T. (2011). The MycoBrowser portal: a comprehensive and manually annotated resource for mycobacterial genomes. Tuberculosis, 91(1), $8-13$.

22. Shivangi, Beg, M.A., Meena, L.S. (2018). Insights of Rv2921c (Ftsy) Gene of Mycobacterium tuberculosis H37Rv To Prove Its Significance by Computational Approach. Biomedical Journal of Scientific \& Technical Research, 12(2), 9147 - 9157.

23. Beg, M.A., Shivangi, Thakur, S.C., Meena, L.S. (2019). Systematical analysis to assist the significance of Rv1907c gene with the pathogenic potentials of Mycobacterium tuberculosis H37Rv. Journal of Biotechnology and Biomaterials, 8(4), 286.

24. Sievers, F., Higgins, D.G. (2014). Clustal Omega, accurate alignment of very large numbers of sequences. Methods in Molecular Biology, 1079, 105 - 116.

25. Von Mering, C., Huynen, M., Jaeggi, D., Schmidt, S., Bork, P., Snel, B. (2003). STRING: a database of predicted functional associations between proteins. Nucleic Acids Research, 31(1), 258 - 261.

26. Beg, M.A., Athar, F., Meena, L.S. (2019). Significant Aspect of Rv0378 Gene of Mycobacterium tuberculosis H37Rv Reveals the PE_PGRS like Properties by Computational Approaches. Journal of Biotechnology and Biomedicine, 2(1), 24 - 39.

27. Rashid, M., Saha, S., Raghava, G.P. (2007). Support Vector Machine-based method for predicting subcellular localization of mycobacterial proteins using evolutionary information and motifs. $B M C$ Bioinformatics, 8, 337.

28. Yu, C.S., Cheng, C.W., Su, W.C., Chang, K.C., Huang, S.W., Hwang, J.K., Lu, C.H. (2014). CELLO2GO: a web server for protein subCELlular LOcalization prediction with functional gene ontology annotation. PLoS One, 9(6), e99368.

29. Beg, M.A., Shivangi, Athar, F., Meena, L.S. (2018). Structural and Functional Annotation of Rv1514c Gene of Mycobacterium tuberculosis H37Rv As Glycosyl Transferases. Journal of Advanced Research in Biotechnology, 3(2), 1 -9.

30. Bowie, J.U., Lüthy, R., Eisenberg, D. (1991). A method to identify protein sequences that fold into a known three-dimensional structure. Science, 253(5016), $164-170$.

31. Buchan, D.W.A., Jones, D.T. (2019). The PSIPRED Protein Analysis Workbench: 20 years on. Nucleic Acids Research, 47(W1), 402 - 407.

32. Beg, M.A., Thakur, S.C., Athar, F. (2020). Computational annotations of mycobacterial Rv3632 that confers its efficient function in cell wall biogenesis. Journal of Bacteriology \& Mycology: Open Access, 8(2),46 - 53. 
33. Ma, J., Wang, S., Zhao, F., Xu, J. (2013). Protein threading using context-specific alignment potential. Bioinformatics, 29(13), $257-265$.

34. Biasini, M., Bienert, S., Waterhouse, A., Arnold, K., Studer, G., Schmidt, T., Kiefer, F., Gallo Cassarino, T., Bertoni, M., Bordoli, L., Schwede, T. (2014). SWISS-MODEL: modelling protein tertiary and quaternary structure using evolutionary information. Nucleic Acids Research, 42(Web Server issue), $252-258$.

35. Beg, M.A., Thakur, S.C., Athar, F. (2020). Molecular modeling and in silico characterization of mycobacterial Rv3101c and Rv3102c proteins: prerequisite molecular target in cell division. Pharmacy \& Pharmacology International Journal, 8(4), 234 - 243.

36. Ho, B.K., Brasseur, R. (2005). The Ramachandran plots of glycine and pre-proline. BMC Structural Biology, 5,14.

37. Cristobal, S., Zemla, A., Fischer, D., Rychlewski, L., Elofsson, A. (2001). A study of quality measures for protein threading models. BMC Bioinformatics, 2,5.

38. Wallner, B., Elofsson, A. (2003). Can correct protein models be identified? Protein Science, 12(5), $1073-1086$.

39. Beg, M.A., Athar, F. (2020). Anti-HIV and Anti-HCV drugs are the putative inhibitors of RNAdependent-RNA polymerase activity of NSP12 of the SARS CoV- 2 (COVID-19). Pharmacy \& Pharmacology International Journal, 8(3), 163 - 172.

40. Trott, O., Olson, A.J. (2010). Auto Dock Vina: improving the speed and accuracy of docking with a new scoring function, efficient optimization, and multithreading. Journal of Computational Chemistry, 31(2), $455-461$.

41. Beg, M.A., Athar, F. (2020). Pharmacokinetic and molecular docking studies of Achyranthes aspera phytocompounds to exploring potential anti-tuberculosis activity. Journal of Bacteriology \& Mycology: Open Access, 8(1), 18 - 27.

42. Biovia, D.S. (2015). Discovery studio modelling environment. San Diego. Dassault Systems.

43. Beg, M.A., Athar, F. (2020). Computational method in COVID-19: Revelation of Preliminary mutations of RdRp of SARS CoV-2 that build new horizons for therapeutic development. Journal of Human Virology \& Retrovirology, 8(3), 62 - 72.

44. Rodrigues, C.H., Pires, D.E., Ascher, D.B. (2018). DynaMut: predicting the impact of mutations on protein conformation, flexibility and stability. Nucleic Acids Research, 46(W1), 350 - W355.

45. Shivangi, Beg, M.A., Meena, L.S. (2019). Mutational effects on structural stability of SRP pathway dependent cotranslational protein $\mathrm{fts} Y$ of Mycobacterium tuberculosis $\mathrm{H}_{37} \mathrm{Rv}$. Gene Reports, 15, 100395 .

46. Beg, M. A., Hejazi, I. I., Thakur, S. C., \& Athar, F. (2021). Domain-wise differentiation of Mycobacterium tuberculosis $\mathrm{H}_{37} \mathrm{Rv}$ hypothetical proteins: A roadmap to discover bacterial survival potentials. Biotechnology and applied biochemistry, 10.1002/bab.2109.

47. Hejazi, I. I., Beg, M. A., Imam, M. A., Athar, F., \& Islam, A. (2021). Glossary of phytoconstituents: Can these be repurposed against SARS CoV-2? A quick in silico screening of various phytoconstituents from plant Glycyrrhiza glabra with SARS CoV-2 main protease. Food and 
chemical toxicology : an international journal published for the British Industrial Biological Research Association, 150, 112057. Advance online publication.

https://doi.org/10.1016/j.fct.2021.112057 